\title{
THE STUDY OF CONSUMER ASPECTS OF MEDICAL PRODUCTS FOR DIAGNOSIS OF PREGNANCY
}

\author{
T.V.Diadiun, I.I.Baranova, A.O.Lytovchenko \\ National University of Pharmacy
}

Key words: human chorionic gonadotropin; pregnancy test; consumer aspects; pregnancy diagnosing

\begin{abstract}
To diagnose pregnancy means to ascertain the fact of pregnancy and its duration. Timely and accurate diagnosis of pregnancy and determination of its term are needed to prevent complications, premature birth and prolongation. There are several kinds of tests for pregnancy at the market such as conventional test strips, tablets, midstream sticks and electronic tests. Medical products for diagnosis of pregnancy are widely popular among women because of their high efficiency and reliability of the results. The leaders among manufacturing countries are Canada, Germany and the USA. It has been found that there are tests with different sensitivity of 30,25, 20 and $10 \mathrm{Mme} / \mathrm{ml}$. The least sensitive are simple strips (20$15 \mathrm{mIU} / \mathrm{ml}$ ), and midstream sticks have the highest sensitivity $(10 \mathrm{~m} / \mathrm{U} / \mathrm{mL})$. The analysis of sensitivity indicators of tests has been conducted using of the standards WHO IS 75/537 and IRP 75/537. It has been found that such tests as Sezam, HomeTest and ULTRA, which can be used on the 7th day after fertilization, have the highest sensitivity.
\end{abstract}

According to the Ministry of Public Health, Ukraine ranks the fifth place by population among the European countries and the second place among the CIS countries. But, unfortunately, a deplorable fact is that for over 20 years in Ukraine the annual number of deaths exceeds the number of births [4]. Therefore, there is an urgent need for early diagnosis of pregnancy; it allows to follow specific recommendations for its preservation, appropriate correction of the life plans of future parents; diet, work, sexual activity and other aspects of the life of a pregnant woman.

To diagnose pregnancy means to ascertain the fact of pregnancy and its duration. Timely and accurate diagnosis of pregnancy and determination of its term are needed to prevent complications, premature birth and prolongation. In addition, early diagnosis of pregnancy can eliminate the influence of harmful factors in the first weeks of pregnancy [7].

Today, there is a number of methods for diagnosis of pregnancy used both in hospitals and at home. These methods differ in a number of features, higher or lower specificity and reliability. Pregnancy tests are the most widely used.

A pregnancy test is a rapid qualitative immunochromatographic test to determine human chorionic gonadotropin (hCG) in urine samples [5, 6]. Human chorionic gonadotropin is a glycoprotein hormone produced from the first hours of pregnancy $[6,9]$. The analysis of the literature data shows that in the normal course of pregnancy hCG is found in the urine soon after conception and reaches the level of 5-50 $\mathrm{mIU} / \mathrm{ml}$ during the first week of pregnancy $[8,11]$. Over the next 10 weeks the level of its concentration increases rapidly and reaches 100000 $200000 \mathrm{mIU} / \mathrm{ml}$ at the end of the first trimester. The presence of hCG in the urine soon after conception and the rapid increase in its concentration is an indicator of pregnancy $[1,2]$. It is known that in women with early terms of pregnancy the hCG level is approximately the same, and it is this fact that makes it an ideal marker for quick and accurate determination of pregnancy $[9,10]$.

There are several kinds of tests for pregnancy at the market such as conventional test strips, tablets, midstream sticks and electronic tests.

Test strips are required to be immersed in a container with the urine, so some inconvenience of their use is the need to use a separate container for collection of the urine, as well as there is the probability of an erroneous test result.

Tablet tests are a plastic box with two holes. In one of them a few drops of urine are put (for this purpose a pack contains a pipette), the second hole is for observing results. Their drawback is also the need for additional container for collection of the urine into the pipette.

Midstream sticks of the third generation are more convenient and accurate. For testing there is no need to collect urine, in addition, they can be used at any time of the day [3].

Electronic tests, which allow to get a definite answer about the presence or absence of pregnancy, work on the principle of previous products, but have a much higher price. Application of the latest technologies has allowed to provide a woman with such modern product as reusable pregnancy test. It provides almost one hundred percent accuracy, can be reused (up to 20 times) and has the additional function of calculating the probable date of birth.

The aim of the work was to study the range and indices of consumer properties of pregnancy tests presented at the pharmaceutical market of Ukraine.

\section{Materials and Methods}

The work analyzes the market of medical products for diagnosis of pregnancy presented by many domestic and foreign manufacturers. Dependence of sensitivity of tests on the term of the possible pregnancy determination has been also found. 
MANUFACTURING COUNTRIES

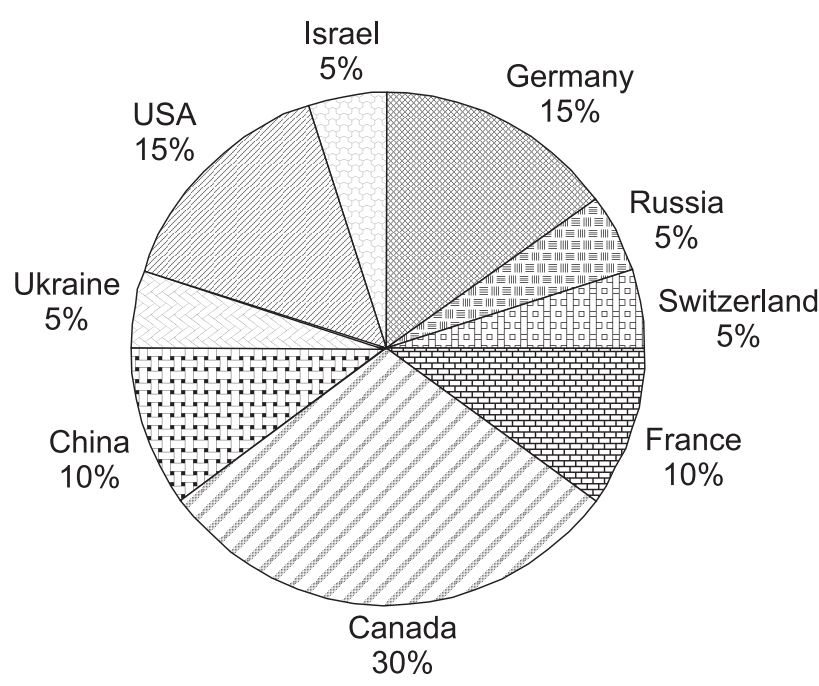

Fig. 1. Manufacturing countries of products for pregnancy diagnosing presented at the Ukrainian market.

\section{Results and Discussion}

Medical products for diagnosis of pregnancy are widely popular among women because of their high efficiency and reliability of the results. The leaders among manufacturing countries are Canada, Germany and the USA (Fig. 1, Tab. 1) [2, 3].

One of the factors when choosing a pregnancy test is its sensitivity, which is usually indicated on the pack or in the package insert for the product. The lower concentration of the hormone in the urine the test is able to recognize, the more sensitive it is. It has been found that there are tests with different sensitivity of 30,25 , 20 and $10 \mathrm{Mme} / \mathrm{ml}$. The least sensitive are simple strips (20-15 $\mathrm{mIU} / \mathrm{ml})$, and midstream sticks have the highest sensitivity $(10 \mathrm{mIU} / \mathrm{mL})$. We have also clarified the relationship between sensitivity of tests and the pregnancy term in which they can be used (Tab. 2).

The analysis of sensitivity indicators of tests has been conducted using of the standards WHO IS 75/537 and IRP 75/537. It has been found that such tests as Sezam,
The range of pregnancy tests presented at the Ukrainian market

\begin{tabular}{|l|l|l|}
\hline \multicolumn{1}{|c|}{ Trade name } & \multicolumn{1}{|c|}{ Manufacturer } & \multicolumn{1}{c|}{$\begin{array}{c}\text { Country } \\
\text { of origin }\end{array}$} \\
\hline Frautest & Human Gesellschaft & Germany \\
\hline Evitest & Helm & Germany \\
\hline Be sure & $\begin{array}{l}\text { Progressive BIO MED } \\
\text { Technologies }\end{array}$ & Russia \\
\hline Test FOR Best & Schonen & Switzerland \\
\hline BB Test & Innotech International & France \\
\hline Cameo & Pharmascience & Canada \\
\hline Miss & World of Health Biotech & China \\
\hline Bona & Tespro & Ukraine \\
\hline Be sure & Ind diagnostic Inc. & Canada \\
\hline Clear Girl & ZER HITECH & Israel \\
\hline Babychek & VEDA-LAB & France \\
\hline Evidence & LEB-International & USA \\
\hline Answer & LEB-International, & USA \\
\hline My SECRET & Ind diagnostic Inc., & Canada \\
\hline My SECRET-Lux & Ind diagnostic Inc. & Canada \\
\hline Nouwelle & Ind diagnostic Inc. & Canada \\
\hline Secret & ACON LABS & USA \\
\hline Duet & IND diagnostic Inc. & Canada \\
\hline Ultra & ACON BIOTECH & China \\
\hline ITEST & AXIOM & Germany \\
\hline
\end{tabular}

Table 2

Dependence of sensitivity of the tests on the term of pregnancy

\begin{tabular}{|c|c|}
\hline $\begin{array}{c}\text { Sensitivity of } \\
\text { the test, } \mathrm{mlU} / \mathrm{ml}\end{array}$ & \multicolumn{1}{c|}{$\begin{array}{c}\text { The possibility of determining } \\
\text { pregnancy }\end{array}$} \\
\hline $10 \mathrm{mlU} / \mathrm{ml}$ & On the 7th day after fertilization \\
\hline $20 \mathrm{mlU} / \mathrm{ml}$ & On the 7-10th day after fertilization \\
\hline $25 \mathrm{mlU} / \mathrm{ml}$ & From the 1st day after the missed period \\
\hline
\end{tabular}

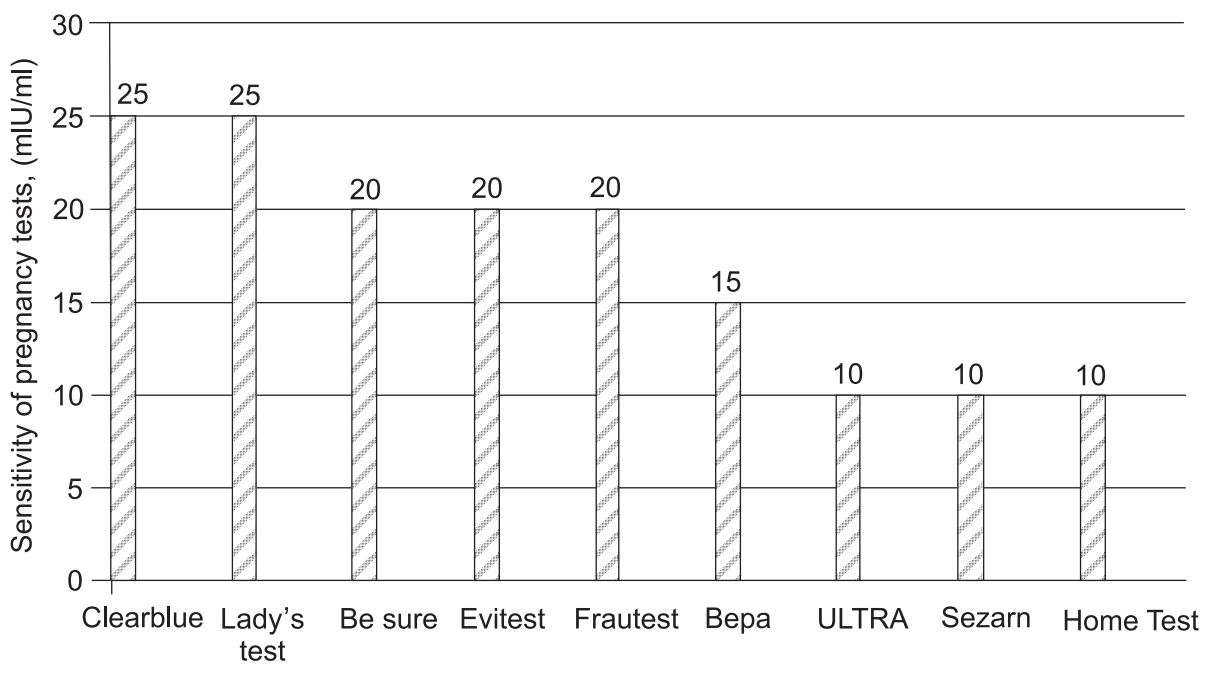

Trade names of pregnancy tests

Fig. 2. Sensitivity of pregnancy tests. 
HomeTest and ULTRA, which can be used on the 7th day after fertilization, have the highest sensitivity (Fig. 2).

Based on the data from the literature sources it has been found that pregnancy tests can be stored at low (refrigerator) and room temperature (between $2^{\circ} \mathrm{C}$ to $30^{\circ} \mathrm{C}$ ). Their stability preserves until the expiration date (24 months from the date of manufacture). These data indicate that the given products do not require special storage conditions, and it is a positive consumer characteristic.

\section{CONCLUSIONS}

The analysis of the pharmaceutical market of Ukraine where medical products in the form of pregnancy tests are presented has shown that the leaders among manufacturing countries are Canada, Germany and the USA.

The analysis of sensitivity indicators of pregnancy tests has revealed that such tests as Sezam, HomeTest and ULTRA, which can be used on the 7th day after fertilization, have the highest sensitivity.

\section{REFERENCES}

1. Агаджанян Н.А., Тель Л.З., Циркин В.И., Чеснокова С.А. Физиология человека. - М.: Медииинская книга, Н. Новгород: Изд-во НГМА, 2005. - 526 с.

2. Агаджсанян Н.А., Баевский Р.М., Берсенева А.П. Учение о здоровье и проблемы адаптации. - М.: Изд-во РУДЫ, 2006. - 204 c.

3. Колипова Ю.В. // Фармаи. вестник. - 2004. - №13 (334). - С. 31.

4. Результати діяльності галузі охорони здоров'я України: 2013 p. - К., 2014. - 6 c.

5. Энциклопедия «Жизнь и здоровье женщины»». - Т. 2. - Изд. 2-е, испр. и доп. - М.: АНС, 2003. - 816 c.

6. Baird D.D., Weinberg C.R., McConnaughey D.R. et al. // Biol. Reprod. - 2003. - №68 (2). - P. 448-456.

7. Fozan H.A., Tulandi T. // Curr. Opin. Obstet. Gynecol. - 2002. - Vol. 14, №4. - P. 375-379.

8. Johnson S.R., Miro F., Barrett S. et al. // Curr. Med. Res. Opin. - 2009. - №25. - P. 741-748.

9. Johnson S., Perry P., Alonzo T. et al. // Clin. Chem. - 2013. - S209. - B45.

10. Nepomnaschy P.A., Weinberg C.R., Wilcox A.J. // Hum. Reprod. - 2008. - №23 (2). - P. 271-277.

11. Vaitukaitis J.L. // Ann. N.Y. Acad. Sci. - 2004. - №1038. - P. 220-222.

\section{ДОСЛІДЖЕННЯ СПОЖИВЧИХ АСПЕКТІВ ВИРОБІВ МЕДИЧНОГО ПРИЗНАЧЕННЯ ДЛЯ ДІАГНОСТИКИ ВАГІТНОСТІ \\ Т.В.Дядюн, І.І.Баранова, А.О.Литовченко \\ Ключові слова: хоріонічний гонадотропін; тест на вагітність; споживчі аспекти; діагностування вагітності}

Діагностувати вагітність - означає встановити фракт вагітності та ї̈ термін. Своєчасний і точний діагноз вагітності та визначення їі терміну необхідні для профрілактики ускладнень, передчасних пологів і переношування. На ринку представлені декілька видів тестів на вагітність: звичайні тест-смужки, планшетні, струминні та електронні тести. Вироби медичного призначення для діагностики вагітності користуються широкою популярністю серед жінок через свою високу ефективність та достовірність результатів. Лідерами серед країн-виробників є Канада, Німеччина та США. Встановлено, що пропонуються тести з різною чутливістю: 30, 25, 20 і 10 Mme/ml. Найменш чутливими є прості стрип-смуги (20-15 мМО/мл), а найбільшу чутливість мають струминні тести (10 мМО/мл). Аналіз показника чутливості тестів проводився з використанням стандартів BOO3 IS 75/537 та IRP 75/537. Встановлено, що найбільшу чутливість мають mести Sezam, HomeTest i ULTRA, які можна використовувати на 7-й день після запліднення.

\section{ИССЛЕДОВАНИЕ ПОТРЕБИТЕЛЬСКИХ АСПЕКТОВ ИЗДЕЛИЙ МЕДИЦИНСКОГО НАЗНАЧЕНИЯ ДЛЯ ДИАГНОСТИКИ БЕРЕМЕННОСТИ \\ Т.В.Дядюн, И.И.Баранова, А.О.Литовченко}

Ключевые слова: хорионический гонадотропин; тест на беременность; потребительские аспекты; диагностирование беременности

Диагностировать беременность - значит установить фракт беременности и ее срок. Своевременный и точный диагноз беременности и определение ее срока необходимы для профилактики осложнений, преждевременных родов и перенашивания. На рынке представлено несколько видов тестов на беременность: обычные тест-полоски, планшетные, струйные и электронные тесты. Изделия медицинского назначения для диагностики беременности пользуются широкой популярностью среди женщин благодаря своей высокой эффрективности и достоверности результатов. Лидерами среди стран-производителей являются Канада, Германия и США. Установлено, что предлагаются тесты с разной чувствительностью: 30, 25, 20 и $10 \mathrm{Mme} / \mathrm{ml}$. Наименее чувствительными являются простые стрип-полоски (20-15 мМО/мл), а наибольшую чувствительность имеют струйные тесты (10 мMO/мл). Анализ показателя чувствительности тестов проводился с использованием стандартов ВОЗ IS 75/537 и IRP 75/537. Установлено, что наибольшую чувствительность имеют тесты Sezam, HomeTest u ULTRA, которые можно использовать на 7-й день после оплодотворения. 